\title{
Suboptimal Immune Reconstitution in Vertically HIV Infected Children: A View on How HIV Replication and Timing of HAART Initiation Can Impact on $T$ and B-cell Compartment
}

\author{
Nicola Cotugno, ${ }^{1}$ Iyadh Douagi, ${ }^{2}$ Paolo Rossi, ${ }^{1,3}$ and Paolo Palma ${ }^{3}$ \\ ${ }^{1}$ University of Rome, Tor Vergata, 00133 Rome, Italy \\ ${ }^{2}$ Department of Medicine, Karolinska Institute, SE-141 86 Stockholm, Sweden \\ ${ }^{3}$ University Department of Pediatrics, DPUO, Children' Hospital Bambino Gesù, Piazza S.Onofrio, 4-00165 Rome, Italy
}

Correspondence should be addressed to Paolo Palma, paolo.palma@opbg.net

Received 29 September 2011; Revised 21 November 2011; Accepted 10 December 2011

Academic Editor: Mirko Paiardini

Copyright ( $\odot 2012$ Nicola Cotugno et al. This is an open access article distributed under the Creative Commons Attribution License, which permits unrestricted use, distribution, and reproduction in any medium, provided the original work is properly cited.

Today, HIV-infected children who have access to treatment face a chronic rather than a progressive and fatal disease. As a result, new challenges are emerging in the field. Recent lines of evidence outline several factors that can differently affect the ability of the immune system to fully reconstitute and to mount specific immune responses in children receiving HAART. In this paper, we review the underlying mechanisms of immune reconstitution after HAART initiation among vertically HIV-infected children analyzing the possible causes of suboptimal responses.

\section{Introduction}

Highly active antiretroviral treatment (HAART) has dramatically changed the course of HIV infection, allowing control of viral replication and the restoration of immune function [1]. However, the success currently experienced in many patients receiving HAART remains far from universal or permanent. Children who have been highly compliant to HAART at younger ages frequently present adherence problems during adolescence [2]. Recent data clearly show how, after five years of continuous HAART, vertically HIV-infected children are at a high risk of developing triple-class virological failure [3]. New lines of evidence outline several factors that can differently affect the ability of the immune system to fully reconstitute and maintain specific immune responses in children under HAART. A better understanding of how HAART affects immunity is needed. Here, we review present knowledge regarding immunity in HIV-infected children, exploring the impact of HIV viral load, HAART, timing of initiation, and age on B- and T-cell recovery and maintenance. In addition, we describe immune responses to vaccinations as a model system to review possible causes of immune memory dysfunction and suboptimal reconstitution in vertically HIV-infected children on HAART.

\section{T-Cell Compartment and HAART}

With initiation of HAART, immune activation declines in parallel to the reconstitution of naïve and memory T-cell subsets [3-6]. Apparently, three mechanisms play a key role in $\mathrm{T}$ cell immune reconstitution process in $\mathrm{HIV}$-infected individuals. De novo production by the thymus plays a crucial role in the rise of mostly naïve $\mathrm{CD}^{+}$in younger patients [6-9], whereas an increase in $\mathrm{CD} 4^{+} \mathrm{T}$ cell half-life and homeostatic proliferation by the residual memory $\mathrm{CD} 4^{+}$ $\mathrm{T}$ cells are predominant mechanisms in older subjects [10]. The ability of the immune system to develop and maintain specific immune responses will depend on the predominance of one of these mechanisms. In fact, even if an absolute $\mathrm{CD}^{+}$T-cell count can be fully restored, T-cell immune reconstitution can be "partial" if it is based on the production 
of new $\mathrm{CD} 4{ }^{+} \mathrm{T}$-cell or "truncated" if it is mainly from the remaining repertoire of $\mathrm{CD}^{+} \mathrm{T}$ cell [11]. Factors such as age, viremia, timing of HAART initiation and involution of the thymus can play a critical role in this process leading to quantitative and qualitative differences in the immune reconstitution.

\section{Factors Leading to Suboptimal Reconstitution of T-Cell Compartment in HIV-Infected Children on HAART}

3.1. HIV Viremia. HIV causes qualitative and quantitative dysfunctions of T-cell compartment in both $\mathrm{CD} 4^{+}$and $\mathrm{CD} 8^{+}$ subsets. Under viral replication, naïve $\mathrm{CD} 4^{+}$and $\mathrm{CD} 8^{+} \mathrm{T}-$ cells are stimulated to enter the circulation and differentiate into effector memory $\left(\mathrm{CD}_{4} 4 \mathrm{RA}^{+} \mathrm{CCR}^{-}\right)$and effector phenotype $\left(\mathrm{CD}^{2} 5 \mathrm{RA}^{-} \mathrm{CCR}^{-}\right)$, while central memory $\left(\mathrm{CD}_{4} \mathrm{RA}^{-} \mathrm{CCR}^{+}\right)$compartment is depleted [12-14]. However, persistent exposure to high levels of viremia results in a dysfunctional immune-specific response to HIV leading to exhaustion of naïve CD8 T-cells and skewed maturation of memory subsets $[15,16]$. Virus-specific CD8 T-cell exhaustion is characterized by the incremental loss of proliferative and effectors properties [17, 18]. Moreover, a continued antigenic stimulation induces an increased expression of surface activation markers, such as HLA-DR and CD38 $[19,20]$. A positive relation between the expression of these markers and $\mathrm{CD} 4^{+}$and $\mathrm{CD} 8^{+}$depletion has been reported [21] and directly related to clinical disease progression in both HIV-infected adults and infants [22, 23]. Persistent HIV viremia has also been related to an increase in $\mathrm{T}$ cell apoptosis. A higher expression of the key regulatory marker of apoptosis (CD95) on $\mathrm{CD}^{+}$has been described during HIV infection [24-26]. Conversely, a significant decrease in CD95 expression, with the reduction of $\mathrm{CD}_{4}^{+}$and $\mathrm{CD} 8^{+} \mathrm{T}$ cells apoptosis, has been observed after HAART initiation in HIV-infected children and adolescents [27]. However, since the reduced apoptosis is restricted to the CD45RO-positive (primed/memory) T-cells subpopulation, the simultaneous increase in circulating resting/naïve $\mathrm{T}$ cells observed in pediatric patients can be explained by the new generation of naïve $\mathrm{T}$ cells from the thymus.

3.2. Quality of Reconstitution: Age Makes the Difference. Previous studies among transplant and chemotherapy recipients indicated that age directly influences immune reconstitution $[28,29]$. In these patients, $C D 4^{+} \mathrm{T}$ naïve or memory expansion specifically contributing to the immune reconstitution ultimately differs according to age.

Similarly, a direct relation between the individuals age, naïve T-cell emigration, and memory T-cell expansion has also been demonstrated in vertically HIV-infected children after HAART initiation [30-33]. Since the patient's age can have an impact on immune reconstitution after HAART initiation, the age of HIV transmission and timing of HAART initiation must be carefully considered [34]. In a cohort of 265 HIV-infected children naïve to treatment, Walker et al. found that the short-term (6 months) CD4\% increase after HAART initiation was positively related to younger age and inversely related to pre-HAART CD4\% [35]. In addition, several authors reported that immune restoration in infants mainly involves naïve cells, while it mostly relies on expansion of memory $\mathrm{T}$ cells in older children $[30,33,35]$. Indeed immune recovery that follows HAART initiation is faster in younger children compared to older ones or adults [36-39]. As shown by multiple studies analyzing thymic output using T-cell receptor excision circle (TRECs) assays [40], thymic function plays a pivotal role in this process [41]. Physiologically, thymus function is inversely related to age. It has been shown that HIV-1-infected children present lower TREC values than health-matched controls and a significant increase in parallel with $\mathrm{CD}^{+}$count after HAART initiation, particularly at younger ages [42]. Thus, to warrant an optimal immune reconstitution, WHO 2010 recommendations suggest the initiation of HAART in all HIV-infected children between two and five years with either a CD4 $4^{+}$count of $750 \mathrm{cell} / \mathrm{mm}^{3}$ or below, or a $\mathrm{CD} 4^{+}$ percentage of 25 or below, whichever is lower, irrespective of clinical status [43].

The relation between age and control of viremia has also been extensively addressed by several authors [30, 34, 39, 44]. Untreated newborns and infants present an higher peak of viremia during acute infection. In addition, younger patient's age has been related to the slower achievement of viral control compared to older one despite effective HAART [45, 46]. The immaturity of the immune system, together with differences in pharmacokinetics and pharmacodynamics of antiviral drugs, may account for a less efficient containment of HIV viral replication during infancy [30].

\subsection{Other Possible Factors Influencing Suboptimal T-Cell Responses}

3.3.1. Use of Different Antiretroviral Drugs Classes. Firstline boosted protease inhibitors (PI) regimens have been recently shown to be equally effective than Nonnucleoside reverse transcriptase inhibitors (NNRTI) ones in terms of immune reconstitution and long-term control of viremia in HIV-infected children [36]. However, small observational studies in vertically HIV-infected children show increased HIV-specific cellular immune responses after switching from a PI to an NNRTI-based regimen [47, 48]. A possible relation between the use of different antiretroviral drug classes and the ability of the immune system to mount T-cell-specific immune responses has been proposed. Several authors have suggested that PI may cause immune suppression by interfering with antigen presentation. In vitro studies [49] showed the ability of PI drugs to modulate proteasome peptidase activity and cause intracellular accumulation of ubiquitin tagged proteins. Increased HIV-specific immune T-cell response, in terms of lymphoproliferation and intracellular IFN- $\gamma$ and tumor necrosis factor- $\alpha$ production, has been described in HIV-infected children who changed to a PI-sparing therapy owing to failure of viral control or due to toxicity $[47,48]$. 
TABLE 1: Factors leading to suboptimal immune reconstitution in vertically HIV infected children.
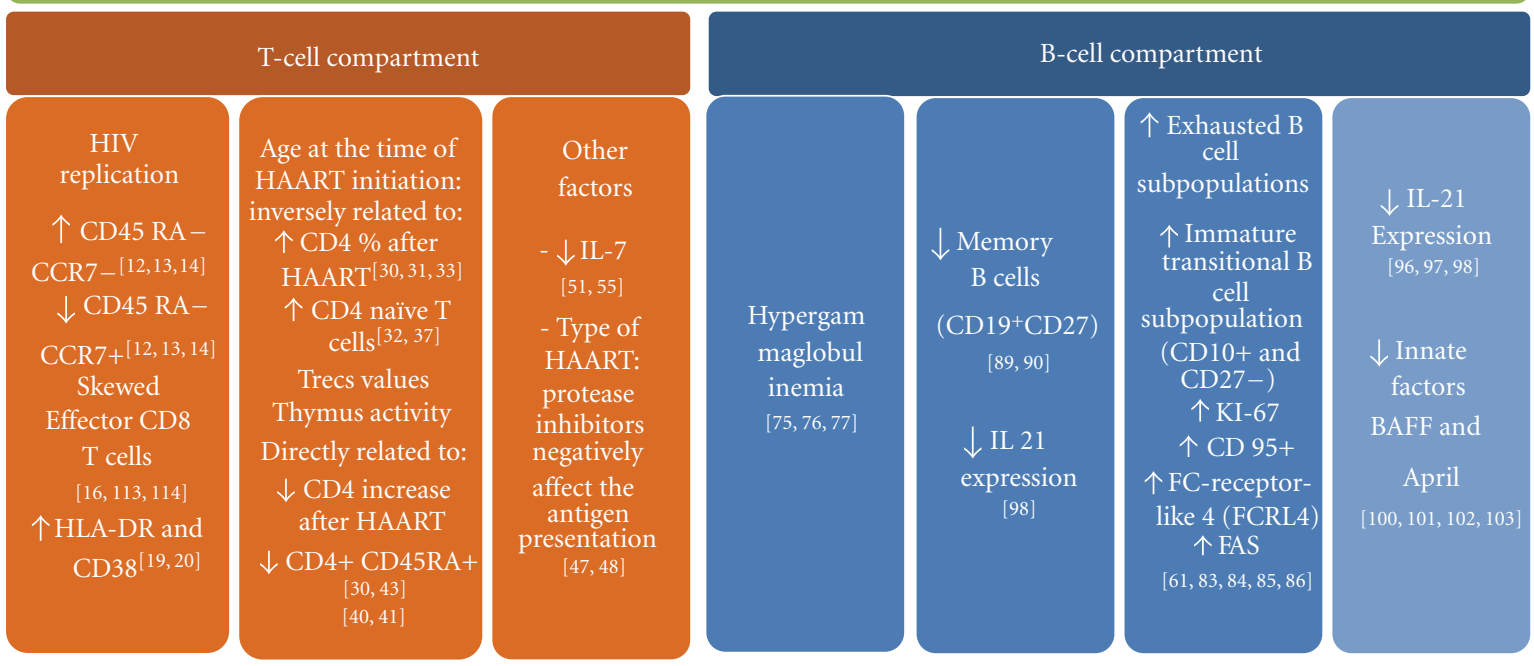

3.3.2. Levels of $I L-7$. The IL-7/IL-7R pathway has been shown to play a key role in sustaining peripheral $\mathrm{CD}^{+}{ }^{+} \mathrm{T}$-cell homeostasis [50, 51].

High levels of IL-7 were demonstrated among HIV-infected adults in association with higher $\mathrm{CD} 4^{+}$depletion [52, 53]. However, data on IL-7 activity in HIV-infected children are discordant and still unclear. The presence of a better higher thymus activity at younger ages may lead to a faster T-cell turnover, resulting in different IL-7 consumption [54, 55]. Therefore, lower IL-7 levels observed among HIVinfected children may result from an increased consumption of IL-7 by newly produced T cells in response to active viral replication. In line with this observation, a strong relation between low levels of IL-7 and extent of HIV viral replication has also been established [56]. Taken together, this may suggest that low levels of IL-7 could be a predictable marker of virological failure in $\mathrm{HIV}$-infected children $[55,56]$.

\section{B-Cells Compartment and HAART}

A decline in total $\mathrm{CD} 27^{+}$memory B-cells, hypergammaglobulinemia [57-59], impaired reactivity or loss of specific antibodies gained during the normal vaccination schedule, increased expression of markers activation [60-62], high spontaneous autoantibody production in vitro [63], and an increased incidence of B-cell malignancies [64] have all been reported as direct and indirect consequences of HIV infection [65] (Table 1).

Hypergammaglobulinemia reflects a generalized HIV-1driven polyclonal B-cell activation and was shown to be directly related to viremia and inversely related to CD4\% [66]. After virologic suppression with HAART, CD4 ${ }^{+}$Tcell count increases, hypergammaglobulinemia decreases to normal levels, and an increase in the absolute CD19+ $\mathrm{B}$-cell count has been observed [67-71].

Furthermore, HAART permits the reduction of Bcells subpopulations that are abnormally expanded during ongoing HIV replication and are prone to apoptosis [72]. In a previous study, we observed a decrease of immature transitional B-cells after achievement of viral suppression through HAART in vertically infected children [54]. Similarly, an expanded population of immature transitional B-cells during uncontrolled viremia and their normalization after HAART initiation has been described in adults $[61,73]$.

These results suggest that effective HAART permits the normalization of B-cell subpopulations and apoptosis-prone $\mathrm{B}$-cell reduction; however, the number and magnitude of Bcell alterations and their qualitative function caused by HIV replication cannot be fully restored by $\operatorname{HAART}[74,75]$.

The following is a review of the factors leading to a suboptimal response of B-cell compartment, focusing on the impaired ability of the immune system to develop an effective B-cell response to infectious agents or vaccinations in HIVinfected children on HAART.

\section{Factors Leading to Suboptimal Response of B-Cell Compartment in HIV-Infected Children on HAART}

\subsection{The Impact of Active HIV Replication}

5.1.1. Hypergammaglobulinemia. Aberrant activation of the B-cell compartment and hypergammaglobulinemia were among the first recognized characteristic of HIV-1-infected individuals $[76,77]$. Although not yet fully matured in children, B-cells are already subject to HIV-induced immune 
activation. Hypergammaglobulinemia and reduced antigenspecific humoral responses in $\mathrm{HIV}$-infected children were first described by Bernstein LJ in 1985 [78]. However, mechanisms responsible for hyperimmunoglobulinemia in HIV infection are unclear. An increased frequency of B-cells secreting high levels of Ig during viremia has been attributed to the expansion of the CD21 $1^{\text {low }}$ B-cell subpopulation in the peripheral blood of HIV-viremic patients. In addition, it has been recently shown that the ligation of virionassociated host CD40L with the cell surface CD40 is sufficient to efficiently activate B-cells in a polyclonal fashion [79]. Whereas it has been reported that viral proteins, such as Nef $[80,81]$ and gp120 [82, 83], can act as triggers for Ig production and dysfunctional switch through a CD40independent pathway.

5.1.2. Abnormal Expansion of B Cell Subpopulations. During HIV infection, different B-cell subpopulations are irreversibly damaged, and markers present on their surface make them dysfunctional and prone to intrinsic and extrinsic modes of apoptosis [84]. In the periphery-active HIV, replication leads to differentiation to plasmablasts [64] and immature transitional B cells with an abnormal expansion of exhausted B-cell subpopulation.

Immature-transitional B-cells $\left(\mathrm{CD} 19^{+} \mathrm{CD} 10^{+} \mathrm{CD} 24^{\text {high }}\right.$ CD38 ${ }^{\text {high }}$ ) represent a critical link between immature B-cells in the bone marrow and mature naïve $\mathrm{B}$-cells, which differentiate into switched memory B-cells, and in turn become overrepresented. This B-cell subpopulation is increased during active HIV replication and has been shown to be related to high levels of viremia, in parallel with a decrease of memory B-cell subset in vertically HIV-infected children [63].

Plasmablasts $\left(\mathrm{CD} 10^{-}\right.$and $\left.\mathrm{CD} 21^{\text {low }}\right)$ show an increased expression of the cell cycle Ki-67 immune proliferation marker and of the death receptor $\mathrm{CD}^{+} 5^{+}$, which have been reported to be related to apoptosis $[61,85]$. In addition, a large proportion of expanded B-cells in HIV-viremic individuals includes a subset of "tissue-like," exhausted Bcells expressing the Fc-receptor-like 4 (FCRL4) and low levels of CD $21^{+}[86,87]$. This subset presents increased expression of multiple inhibitory receptors, altered expression of homing receptors, and reduced proliferative potential [63]. Expansion of all these subsets occurs during active HIV replication and may contribute to the development of suboptimal immune responses.

5.1.3. Loss of Resting Memory B Cell. The persistent high viral replication has been reported to directly affect the Bcell compartment [88, 89]. HIV-infected children show a significant loss of relative and absolute numbers of $\mathrm{CD} 27^{+}$ memory B cells [90]. The loss of mature B cells (CD19 ${ }^{+}$ $\mathrm{CD}_{2} 7^{+}$) impairs long-term maintenance of protective antibodies titers [91-93] and has been shown to persist despite successful HAART $[92,94,95]$. However, the loss of antigenspecific memory B-cell responses begins in the early stages of HIV infection and becomes increasingly evident as the infection progresses to the chronic stage. Indeed, we have reported [92] that numbers of measles-specific memory B cells declined rapidly in vertically infected children who started HAART later than 1 year after birth. Thus, early initiation of HAART may preserve the normal development and long-term maintenance of the memory B cells generated in response to childhood immunizations.

5.1.4. IL-21 Downregulation. The IL-21/IL-21R pathway has recently been identified to play a critical role in the development and maintenance of memory B-cell responses. IL-21 is a T-cell-derived pleiotropic cytokine whose receptor (IL-21R) is expressed by NK, T and B cells, and it seems to play a key role in the activation, expansion, and survival of these cells $[96,97]$. Impaired antigen specific IL-21 secretion by $\mathrm{CD}^{+} \mathrm{T}$ cells in progressive HIV infection has been reported [98]. In a recent study, upregulation of IL-21R on B-cells and IL-21 secretion were proposed as a hallmark to identify responders to $\mathrm{H} 1 \mathrm{~N} 1$ vaccination among HIVinfected adults [98]. However, since IL-21 is produced mainly from $\mathrm{CD}^{+}$cells, in particular from $\mathrm{T}$ follicular helper cells [99], reconstitution of this subset of CD4 T cells with HAART in HIV-infected patients may be critically important to restoring B-cell function. Comparable studies addressing the role of IL-21 in determining the effectiveness of vaccineinduced immune responses in HIV chronically and acutely infected children will contribute to further understand the mechanisms leading to suboptimal immune response in this very particular group of HIV-infected patients. Furthermore, IL-21 production appears to be crucial for antiviral responses. For instance, it has been recently reported in a mouse model, that younger mice, which presented reduced IL-21 levels, showed a suboptimal generation of HBVspecific $\mathrm{CD}^{+} \mathrm{T}$-cell and B-cell responses [100].

5.1.5. Downregulation of BAFF and APRIL. Many studies have identified T-independent mechanisms of modulation of antibodies production [101-103]. Pallikkuth et al. have recently found that two innate immune factors, the $\mathrm{B}$ cell Activating Factor (BAFF) and A Proliferation Inducing Ligand (APRIL), were present at lower levels in HIVinfected adults on HAART not responding to H1N1 vaccine compared to responders [104]. Future efforts are required to dissect the role of $\mathrm{T}$ independent immune factors including $\mathrm{BAFF}$ and APRIL, with the aim to limit $\mathrm{Ab}$ response failure to vaccinations particularly in clinical settings of impaired $\mathrm{T}$ cell Help such as HIV/AIDS, in both adults and infants.

5.1.6. Loss of Maintenance of Protective Antibody Titers. Both primary and secondary $\mathrm{Ab}$ responses are impaired during HIV infection, leading to loss in the maintenance of protective antibody titers which may not be restored by HAART [105]. A recent meta-analysis identified 38 studies in which immune-specific responses were analyzed in vertically infected children [106]. In general, fewer HIV-infected children with achieved protective immunity might experience greater and more rapid waning of protective immunity. Loss of protective humoral responses has been reported in infected children despite successful HAART $[74,77]$. Persistence of measles antibody titers (MAt) $(>50 \mathrm{mIU} / \mathrm{mL}$ 
cut-off value for specific immune response) [107], represents a good experimental model to analyze the longevity of humoral responses in HIV vertically infected children [108]. Protective levels of MAt have been shown to correlate with memory B-cells numbers in healthy individuals and to persist for the entire life span after successful immunization [107]. Generally, impaired development and maintenance of protective MAt has been reported in vertically infected children $[92,107]$. As previously discussed, the decline of resting memory B-cells that occurs during the early stages of HIV infection may be an important pathogenic mechanism linked to the low level of measles-specific antibodies reported in $\mathrm{HIV}$-infected children. In addition, persistent viral replication at the time of immunization can impair the generation and maintenance of protective $\mathrm{Ab}$ titers. Reduced or absent protective Ab titers versus HBV [109] and A H1N1 [110] have been reported in HIV-infected children, who were viremic at the time of vaccination.

Loss of total $\mathrm{CD}^{+}$cells count can also play a crucial role in this process. Noteworthy, emerging data point out the importance of specific CD4 ${ }^{+} \mathrm{T}$ cell subsets depletion such as follicular CCR5 helper cell [99], Tregs, and Th17 which can play a crucial role in the induction and maintenance of protective immune responses [111]. Reduction of follicular CCR5 helper cell has been recently related to lower antibody responses to $\mathrm{H} 1 \mathrm{~N} 1$ vaccination in HIV-infected individuals. Similarly, studies on pandemic H1N1 have shown that specific cellular immune-mediated surveillance is crucially modulated by Th17 and Tregs. Cellular immune response to the influenza virus appears to be lower in HIV-seropositive patients than general population [111].

Reduction of Th17/Treg balance was found in untreated HIV-infected adults and increased after twelve months of HAART initiation as well as the IL-17 level [112]. Similarly, a significant loss of IL-17 producing PBMC was also found in viremic HIV-infected children [113]. A longitudinal assessment of Th17 cell dynamic in the peripheral blood is needed in order to determine the influence of timing of HAART initiation in preserving such subset in HIV-infected children.

\subsection{Timing of Treatment}

5.2.1. Timing of HAART Initiation and Specific Responses to Vaccination. The loss of specific B-cell memory clones occurs during the early stages of HIV infection. Thus, timing of HAART initiation seems to be crucial, since it may result in a different grade of disturbance of B-cell immune reconstitution, especially in pediatric patients. However, very few studies have addressed this issue in childhood [92, 114]. We previously showed that children who began HAART within the first year of life presented levels of memory B-cell percentages comparable to healthy uninfected agematched controls. Conversely, children who began treatment after the first year of life had significantly lower percentages of memory B-cells compared to healthy controls [92]. Furthermore, it was shown that maintenance of resting memory B cell number is related to a better preservation of B-cell memory functionality. Indeed patients treated early maintained protective levels of measles and tetanus antibody titers, mirroring the preservation of B-cell memory repertoire as suggested by ELISpot analysis (Figure 1).

Similarly, early initiation of HAART in infected adults has been shown to prevent irreversible B-cell compartment damage resulting in a more functional profile of memory Bcell responses to HIV and non-HIV antigens when compared with chronic-treated HIV-infected individuals [108]. These data suggest that an early initiation of HAART is needed to preserve B cell compartment and obtaining an optimal response upon vaccination [115]. Whether or not HIV vertically infected children starting HAART later than the first year of life need different vaccine schedule is still debated $[92,105]$.

5.2.2. Timing of HAART Initiation and Specific HIV Response. Timing of HAART initiation can influence the development of HIV-specific immune responses [116-120]. Some authors suggest that a rapid suppression of viral replication during a period of relative immunological immaturity might critically hamper the priming and expansion of virus-specific immune responses in vertically infected children. In fact, it has been shown that vertically infected children starting HAART within the first 3 months achieved long-term viral suppression, but did not develop HIV-specific antibodies and remained seronegative $[30,121-123]$. In line with these data, initiation of HAART during acute HIV infection in adults results in incomplete or absent specific Ab HIV responses [124]. In addition, absent or suboptimal HIV-specific lymphoproliferative and cytotoxic immune responses have been reported by several authors $[117,118,125-128]$. Thus, the control of viremia achieved during different phases of the infection (acute versus chronic) can result in the development of suboptimal or strong HIV-specific immune responses (Figure 1).

\section{Conclusive Remarks}

Vaccination is certainly among the most effective clinical interventions aimed at preventing infectious disease. However, the immune responses obtained following immunization are inadequate in HIV-infected children who present a suboptimal immune reconstitution. The capacity of the immune individuals to respond to vaccinations depends on diverse immunogenetic factors, but also on the degree of immunologic impairment at the time of immunization. The majority of vertically HIV-infected children who have access to antiviral treatment nowadays live into adolescence and adulthood. A large proportion of these children might be susceptible to vaccine-preventable childhood disease. Today, many uncertainties remain about the optimal strategies for identifying such susceptible individuals, and for offering them sustained protection through an appropriate immunization schedule, both in terms of timing and number of vaccine doses [129].

According to the findings presented below, we can highlight two main factors. First, HAART should be administered 


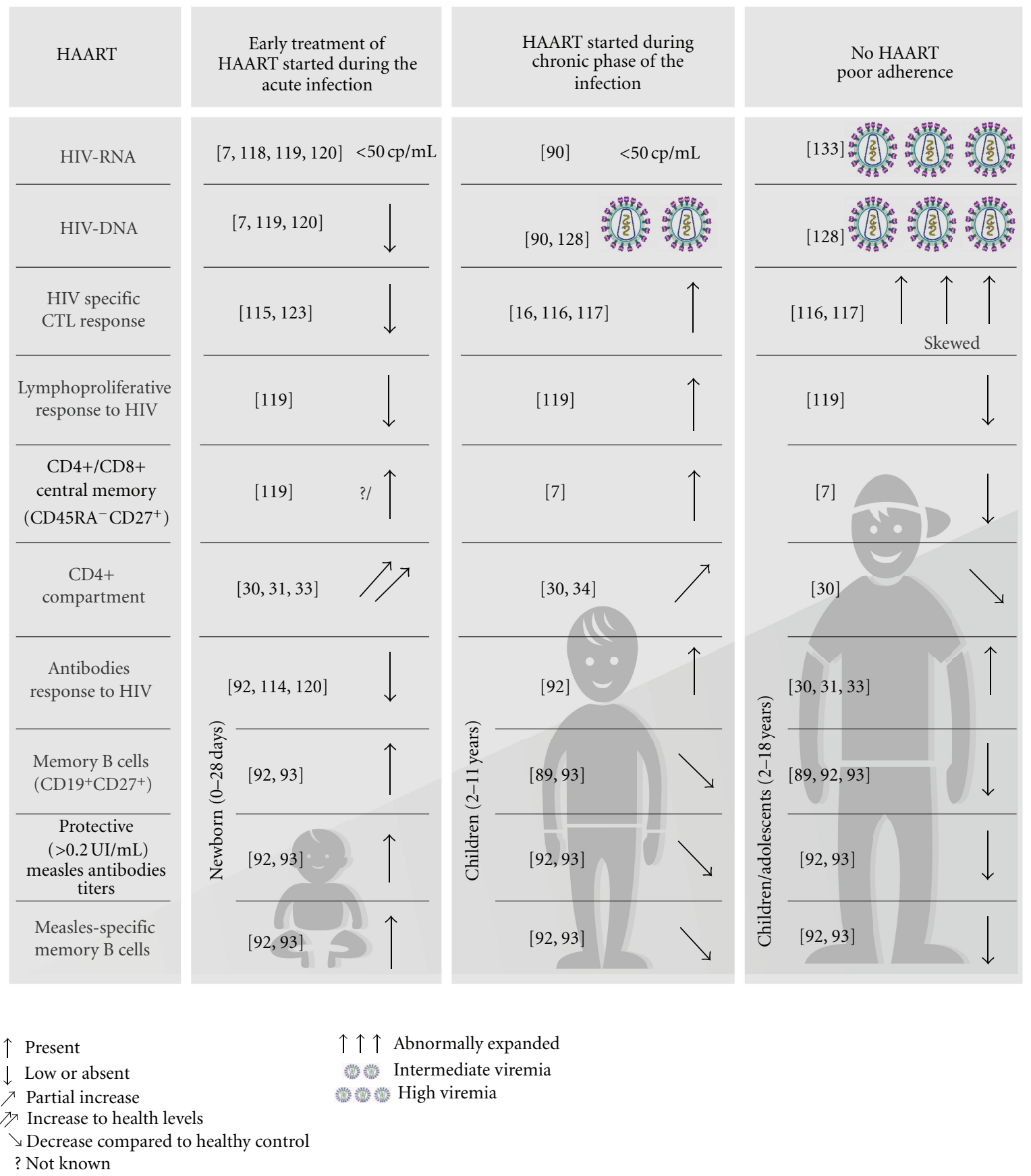

FIGURE 1: How timing of HAART initiation impact on B- and T-cell compartment and on viral replication.

to children during the primary HIV infection to preserve the normal development of specific immune responses. Second, control of viremia should be achieved prior to performing any vaccination since HAART improves the capacity to establish and maintain long-term memory responses in individuals with HIV.

Finally, we also believe that providing an in-depth understanding of the factors that regulate the development of protective immune responses is the sole pathway for rationally devising novel vaccination strategies against emerging infections, particularly in a large group of immune compromised patients, where maintenance of protective immunity clearly remains a major clinical challenge.

\section{Funding}

This study was supported by the Italian Health Institute ISS (AIDSn.40H91) and the Fp6 EU Europrise network of excellence. 


\section{Acknowledgments}

The authors acknowledge Riccardo Truono for providing graphical support, Paola Zangari for bibliography research, and Miss J. Faudella for her precious secretarial work.

\section{References}

[1] S. Resino, J. M. Bellón, D. Micheloud et al., "Clinical outcomes improve with highly active antiretroviral therapy in vertically HIV type-1-infected children," Clinical Infectious Diseases, vol. 43, no. 2, pp. 243-252, 2006.

[2] J. Haberer and C. Mellins, "Pediatric adherence to HIV antiretroviral therapy," Current HIV/AIDS Reports, vol. 6, no. 4, pp. 194-200, 2009.

[3] H. Castro, A. Judd, D. M. Gibb et al., "Risk of tripleclass virological failure in children with HIV: a retrospective cohort study," The Lancet, vol. 377, no. 9777, pp. 1580-1587, 2011.

[4] A. Guihot, R. Tubiana, G. Breton et al., "Immune and virological benefits of 10 years of permanent viral control with antiretroviral therapy," AIDS, vol. 24 , no. 4, pp. 614-617, 2010.

[5] G. R. Kaufmann, L. Perrin, G. Pantaleo et al., "CD4 Tlymphocyte recovery in individuals with advanced HIV-1 infection receiving potent antiretroviral therapy for 4 years: the Swiss HIV cohort study," Archives of Internal Medicine, vol. 163, no. 18, pp. 2187-2195, 2003.

[6] A. De Rossi, A. S. Walker, N. Klein, D. De Forni, D. King, and D. M. Gibb, "Increased thymic output after initiation of antiretroviral therapy in human immunodeficiency virus type 1-infected children in the Paediatric European Network for Treatment of AIDS (PENTA) 5 trial," Journal of Infectious Diseases, vol. 186, no. 3, pp. 312-320, 2002.

[7] A. Anselmi, D. Vendrame, O. Rampon, C. Giaquinto, M. Zanchetta, and A. De Rossi, "Immune reconstitution in human immunodeficiency virus type 1 -infected children with different virological responses to anti-retroviral therapy," Clinical and Experimental Immunology, vol. 150, no. 3, pp. 442-450, 2007.

[8] A. De Rossi, A. S. Walker, D. De Forni, N. Klein, and D. M. Gibb, "Relationship between changes in thymic emigrants and cell-associated HIV-1 DNA in HIV-1-infected children initiating antiretroviral therapy," Antiviral Therapy, vol. 10, no. 1, pp. 63-71, 2005.

[9] S. Resino, I. Galán, A. Pérez et al., "HIV-infected children with moderate/severe immune-suppression: changes in the immune system after highly active antiretroviral therapy," Clinical and Experimental Immunology, vol. 137, no. 3, pp. 570-577, 2004.

[10] G. G. Steinmann, "Changes in the human thymus during aging," Current Topics in Pathology, vol. 75, pp. 43-88, 1986.

[11] P. Corbeau and J. Reynes, "Immune reconstitution under antiretroviral therapy: the new challenge in HIV-1 infection," Blood, vol. 117, no. 21, pp. 5582-5590, 2011.

[12] D. C. Douek, J. M. Brenchley, M. R. Betts et al., "HIV preferentially infects HIV-specific CD4+ T cells," Nature, vol. 417, no. 6884, pp. 95-98, 2002.

[13] K. Ladell, M. K. Hellerstein, D. Cesar, R. Busch, D. Boban, and J. M. McCune, "Central memory CD8+ T cells appear to have a shorter lifespan and reduced abundance as a function of HIV disease progression," Journal of Immunology, vol. 180, no. 12, pp. 7907-7918, 2008.
[14] M. Schenal, S. Lo Caputo, F. Fasano et al., "Distinct patterns of HIV-specific memory T lymphocytes in HIV-exposed uninfected individuals and in HIV-infected patients," AIDS, vol. 19, no. 7, pp. 653-661, 2005.

[15] H. Shin and E. J. Wherry, "CD8 T cell dysfunction during chronic viral infection," Current Opinion in Immunology, vol. 19, no. 4, pp. 408-415, 2007.

[16] C. Montesano, A. Anselmi, P. Palma et al., "HIV replication leads to skewed maturation of CD8-positive T-cell responses in infected children," New Microbiologica, vol. 33, no. 4, pp. 303-309, 2010.

[17] L. Trautmann, L. Janbazian, N. Chomont et al., "Upregulation of PD-1 expression on HIV-specific CD8+ T cells leads to reversible immune dysfunction," Nature Medicine, vol. 12, no. 10, pp. 1198-1202, 2006.

[18] M. Catalfamo, M. Di Mascio, Z. Hu et al., "HIV infectionassociated immune activation occurs by two distinct pathways that differentially affect CD4 and CD8 T cells," Proceedings of the National Academy of Sciences of the United States of America, vol. 105, no. 50, pp. 19851-19856, 2008.

[19] H. N. Ho, L. E. Hultin, R. T. Mitsuyasu et al., "Circulating HIV-specific CD8+ cytotoxic T cells express CD38 and HLADR antigens," Journal of Immunology, vol. 150, no. 7, pp. 3070-3079, 1993.

[20] L. Kestens, G. Vanham, C. Vereecken et al., "Selective increase of activation antigens HLA-DR and CD38 on CD4+CD45RO+ T lymphocytes during HIV-1 infection," Clinical and Experimental Immunology, vol. 95, no. 3, pp. 436-441, 1994.

[21] F. Ensoli, V. Fiorelli, C. Alario et al., "Decreased T cell apoptosis and T cell recovery during highly active antiretroviral therapy (HAART)," Clinical Immunology, vol. 97, no. 1, pp. 9-20, 2000.

[22] J. V. Giorgi, L. E. Hultin, J. A. McKeating et al., "Shorter survival in advanced human immunodeficiency virus type 1 infection is more closely associated with T lymphocyte activation than with plasma virus burden or virus chemokine coreceptor usage," Journal of Infectious Diseases, vol. 179, no. 4, pp. 859-870, 1999.

[23] M. D. Hazenberg, S. A. Otto, B. H. B. Van Benthem et al., "Persistent immune activation in HIV-1 infection is associated with progression to AIDS," AIDS, vol. 17, no. 13, pp. 1881-1888, 2003.

[24] T. Böhler, I. Herr, K. M. Debatin et al., "Downregulation of increased CD95 (APO-1/Fas) ligand in $\mathrm{T}$ cells from human immunodeficiency virus-type 1-infected children after antiretroviral therapy," Blood, vol. 90, no. 2, pp. 886888, 1997.

[25] K. M. Debatin, A. Fahrig-Faissner, S. Enenkel-Stoodt, W. Kreuz, A. Benner, and P. H. Krammer, "High expression of APO-1 (CD95) on T lymphocytes from human immunodeficiency virus-1-infected children," Blood, vol. 83, no. 10, pp. 3101-3103, 1994.

[26] C. B. Bäumler, T. Böhler, I. Herr, A. Benner, P. H. Krammer, and K. M. Debatin, "Activation of the CD95 (APO-1/Fas) system in $\mathrm{T}$ cells from human immunodeficiency virus type1-infected children," Blood, vol. 88, no. 5, pp. 1741-1746, 1996.

[27] T. Böhler, J. Walcher, G. Hölzl-Wenig et al., "Early effects of antiretroviral combination therapy on activation, apoptosis and regeneration of T cells in HIV-1-infected children and adolescents," AIDS, vol. 13, no. 7, pp. 779-789, 1999. 
[28] C. L. Mackall, T. A. Fleisher, M. R. Brown et al., "Age, thymopoiesis, and CD4+ T-lymphocyte regeneration after intensive chemotherapy," New England Journal of Medicine, vol. 332, no. 3, pp. 143-149, 1995.

[29] J. Storek, R. P. Witherspoon, and R. Storb, “T cell reconstitution after bone marrow transplantation into adult patients does not resemble $\mathrm{T}$ cell development in early life," Bone Marrow Transplantation, vol. 16, no. 3, pp. 413-425, 1995.

[30] A. Prendergast, G. Tudor-Williams, P. Jeena, S. Burchett, and P. Goulder, "International perspectives, progress, and future challenges of paediatric HIV infection," Lancet, vol. 370, no. 9581, pp. 68-80, 2007.

[31] A. Vigano, S. Vella, M. Saresella et al., "Early immune reconstitution after potent antiretroviral therapy in HIV-infected children correlates with the increase in thymus volume," AIDS, vol. 14, no. 3, pp. 251-261, 2000.

[32] D. C. Douek, R. D. McFarland, P. H. Keiser et al., "Changes in thymic function with age and during the treatment of HIV infection," Nature, vol. 396, no. 6712, pp. 690-695, 1998.

[33] M. Hainaut, M. Ducarme, L. Schandené et al., "Age-related immune reconstitution during highly active antiretroviral therapy in human immunodeficiency virus type 1-infected children," Pediatric Infectious Disease Journal, vol. 22, no. 1, pp. 62-69, 2003.

[34] K. Patel, M. A. Hernán, P. L. Williams et al., "Long-term effects of highly active antiretroviral therapy on CD4 + cell evolution among children and adolescents infected with HIV: 5 years and counting," Clinical Infectious Diseases, vol. 46, no. 11, pp. 1751-1760, 2008.

[35] A. S. Walker, K. Doerholt, M. Sharland, and D. M. Gibb, "Response to highly active antiretroviral therapy varies with age: the UK and Ireland Collaborative HIV Paediatric Study," AIDS, vol. 18, no. 14, pp. 1915-1924, 2004.

[36] D. M. Gibb, A. Newberry, N. Klein, A. De Rossi, I. GroschWoerner, and A. Babiker, "Immune repopulation after HAART in previously untreated HIV-1-infected children," Lancet, vol. 355, no. 9212, pp. 1331-1332, 2000.

[37] M. M. Lederman, R. McKinnis, D. Kelleher et al., "Cellular restoration in HIV infected persons treated with abacavir and a protease inhibitor: age inversely predicts naive CD4 cell count increase," AIDS, vol. 14, no. 17, pp. 2635-2642, 2000.

[38] J. W. Sleasman, R. P. Nelson, M. M. Goodenow et al., "Immunoreconstitution after ritonavir therapy in children with human immunodeficiency virus infection involves multiple lymphocyte lineages," Journal of Pediatrics, vol. 134, no. 5, pp. 597-606, 1999.

[39] J. P. Aboulker, A. Babiker, M. L. Chaix et al., "Highly active antiretroviral therapy started in infants under 3 months of age: 72-week follow-up for CD4 cell count, viral load and drug resistance outcome," AIDS, vol. 18, no. 2, pp. 237-245, 2004.

[40] P. L. A. Fraaij, G. Verweel, A. M. C. Van Rossum et al., "Sustained viral suppression and immune recovery in HIV type 1-infected children after 4 years of highly active antiretroviral therapy," Clinical Infectious Diseases, vol. 40, no. 4, pp. 604608, 2005.

[41] P. L. A. Fraaij, G. Verweel, A. M. C. Van Rossum et al., "Sustained viral suppression and immune recovery in HIV type 1-infected children after 4 years of highly active antiretroviral therapy," Clinical Infectious Diseases, vol. 40, no. 4, pp. 604608, 2005.

[42] J. W. Mellors, A. Muñoz, J. V. Giorgi et al., "Plasma viral load and CD4+ lymphocytes as prognostic markers of HIV-1 infection," Annals of Internal Medicine, vol. 126, no. 12, pp. 946-954, 1997.

[43] World Health Organization, "Antiretroviral Therapy for HIV infection in infants and children," 2010, http://www.who .int/hiv/pub/paediatric/infants2010/en/index.html.

[44] C. Sabin, "Response to combination antiretroviral therapy: variation by age," AIDS, vol. 22, no. 12, pp. 1463-1473, 2008.

[45] Paediatric European Network for Treatment of AIDS (PENTA), "72- week follow-up of HAART started in infants aged less than 3 months: CD4, viral load and drug resistance outcomes," AIDS, vol. 18, pp. 237-245, 2004.

[46] A. Faye, C. Bertone, J. P. Teglas et al., "Early multitherapy including a protease inhibitor for human immunodeficiency virus type 1-infected infants," Pediatric Infectious Disease Journal, vol. 21, no. 6, pp. 518-525, 2002.

[47] P. Palma, M. L. Romiti, C. Cancrini et al., "Successful simplification of protease inhibitor-based HAART with triple nucleoside regimens in children vertically infected with HIV," AIDS, vol. 21, no. 18, pp. 2465-2472, 2007.

[48] F. A. Legrand, J. Abadi, K. A. Jordan et al., "Partial treatment interruption of protease inhibitors augments HIV-specific immune responses in vertically infected pediatric patients," AIDS, vol. 19, no. 15, pp. 1575-1585, 2005.

[49] M. Piccinini, M. T. Rinaudo, A. Anselmino et al., "The HIV protease inhibitors nelfinavir and saquinavir, but not a variety of HIV reverse transcriptase inhibitors, adversely affect human proteasome function," Antiviral Therapy, vol. 10, no. 2, pp. 215-223, 2005.

[50] E. Bolotin, G. Annett, R. Parkman, and K. Weinberg, "Serum levels of IL-7 in bone marrow transplant recipients: relationship to clinical characteristics and lymphocyte count," Bone Marrow Transplantation, vol. 23, no. 8, pp. 783-788, 1999.

[51] T. J. Fry, E. Connick, J. Falloon et al., "A potential role for interleukin-7 in T-cell homeostasis," Blood, vol. 97, no. 10, pp. 2983-2990, 2001.

[52] A. Malaspina, S. Moir, J. Ho et al., "Appearance of immature/transitional B cells in HIV-infected individuals with advanced disease: correlation with increased IL-7," Proceedings of the National Academy of Sciences of the United States of America, vol. 103, no. 7, pp. 2262-2267, 2006.

[53] D. A. Bazdar, M. Kalinowska, and S. F. Sieg, "Interleukin-7 receptor signaling is deficient in CD4+ T Cells from HIVinfected persons and is inversely associated with aging," Journal of Infectious Diseases, vol. 199, no. 7, pp. 1019-1028, 2009.

[54] A. Cagigi, P. Palma, A. Nilsson et al., "The impact of active HIV-1 replication on the physiological age-related decline of immature-transitional B-cells in HIV-1 infected children," AIDS, vol. 24, no. 13, pp. 2075-2080, 2010.

[55] R. Mazzucchelli and S. K. Durum, "Interleukin-7 receptor expression: intelligent design," Nature Reviews Immunology, vol. 7, no. 2, pp. 144-154, 2007.

[56] M. R. Boulassel, J. Samson, A. Khammy, N. Lapointe, H. Soudeyns, and J. P. Routy, "Predictive value of interleukin-7 levels for virological response to treatment in HIV-1-infected children," Viral Immunology, vol. 20, no. 4, pp. 649-656, 2007.

[57] A. M. Fournier, J. M. Fondere, C. Alix-Panabieres et al., "Spontaneous secretion of immunoglobulins and anti-HIV1 antibodies by in vivo activated B lymphocytes from HIV1-infected subjects: monocyte and natural killer cell requirement for in vitro terminal differentiation into plasma cells," Clinical Immunology, vol. 103, no. 1, pp. 98-109, 2002. 
[58] S. Moir, A. Malaspina, K. M. Ogwaro et al., "HIV-1 induces phenotypic and functional perturbations of $\mathrm{B}$ cells in chronically infected individuals," Proceedings of the National Academy of Sciences of the United States of America, vol. 98, no. 18, pp. 10362-10367, 2001.

[59] W. T. Shearer, K. A. Easley, J. Goldfarb et al., "Prospective 5-year study of peripheral blood $\mathrm{CD} 4+, \mathrm{CD} 8+$, and CD19+/CD20+ lymphocytes and serum Igs in children born to HIV-1+ women," Journal of Allergy and Clinical Immunology, vol. 106, no. 3, pp. 559-566, 2000.

[60] Y. Chong, H. Ikematsu, M. Yamamoto et al., "Increased frequency of CD27- (Naive) B cells and their phenotypic alteration in HIV type 1-infected patients," AIDS Research and Human Retroviruses, vol. 20, no. 6, pp. 621-629, 2004.

[61] S. Moir, A. Malaspina, O. K. Pickeral et al., "Decreased survival of B cells of HIV-viremic patients mediated by altered expression of receptors of the TNF superfamily," Journal of Experimental Medicine, vol. 200, no. 5, pp. 587-599, 2004.

[62] M. Van Der Meijden, J. Gage, E. C. Breen, T. Taga, T. Kishimoto, and O. Martínez-Maza, “IL-6 receptor (CD126'IL-6R') expression is increased on monocytes and B lymphocytes in HIV infection," Cellular Immunology, vol. 190, no. 2, pp. 156166, 1998.

[63] A. Shirai, M. Cosentino, S. F. Leitman-Klinman, and D. M. Klinman, "Human immunodeficiency virus infection induces both polyclonal and virus-specific B cell activation," Journal of Clinical Investigation, vol. 89, no. 2, pp. 561-566, 1992.

[64] O. Martínez-Maza and E. C. Breen, "B-cell activation and lymphoma in patients with HIV," Current Opinion in Oncology, vol. 14, no. 5, pp. 528-532, 2002.

[65] S. Moir and A. S. Fauci, "B cells in HIV infection and disease," Nature Reviews Immunology, vol. 9, no. 4, pp. 235-245, 2009.

[66] The Italian Register, "Combined Antiretroviral therapy reduces Hypergammaglobulinemia in HIV-infected children," AIDS, vol. 18, pp. 1423-1428, 2004.

[67] W. T. Shearer, K. A. Easley, J. Goldfarb et al., "Evaluation of immune survival factors in pediatric HIV-1 infection," Annals of the New York Academy of Sciences, vol. 918, pp. 298$312,2000$.

[68] M. Peruzzi, C. Azzari, L. Galli, A. Vierucci, and M. De Martino, "Highly active antiretroviral therapy restores in vitro mitogen and antigen-specific T-lymphocyte responses in HIV-1 perinatally infected children despite virological failure," Clinical and Experimental Immunology, vol. 128, no. 2, pp. 365-371, 2002.

[69] D. W. Notermans, J. J. De Jong, J. Goudsmit et al., "Potent antiretroviral therapy initiates normalization of hypergammaglobulinemia and a decline in hiv type 1-specific antibody responses," AIDS Research and Human Retroviruses, vol. 17, no. 11, pp. 1003-1008, 2001.

[70] M. A. Jacobson, H. Khayam-Bashi, J. N. Martin, D. Black, and V. Ng, "Effect of long-term highly active antiretroviral therapy in restoring HIV-induced abnormal B-lymphocyte function," Journal of Acquired Immune Deficiency Syndromes, vol. 31, no. 5, pp. 472-477, 2002.

[71] M. M. Lederman, E. Connick, A. Landay et al., "Immunologic responses associated with 12 weeks of combination antiretroviral therapy consisting of Zidovudine, Lamivudine, and Ritonavir: results of AIDS clinical trials group protocol 315," Journal of Infectious Diseases, vol. 178, no. 1, pp. 70-79, 1998.

[72] S. Moir, A. Malaspina, J. Ho et al., "Normalization of B cell counts and subpopulations after antiretroviral therapy in chronic HIV disease," Journal of Infectious Diseases, vol. 197, no. 4, pp. 572-579, 2008.

[73] A. Malaspina, S. Moir, S. M. Orsega et al., "Compromised B cell responses to influenza vaccination in HIV-infected individuals," Journal of Infectious Diseases, vol. 191, no. 9, pp. 1442-1450, 2005.

[74] M. Hart, A. Steel, S. A. Clark et al., "Loss of discrete memory B cell subsets is associated with impaired immunization responses in HIV-1 infection and may be a risk factor for invasive pneumococcal disease," Journal of Immunology, vol. 178, no. 12, pp. 8212-8220, 2007.

[75] K. Titanji, A. De Milito, A. Cagigi et al., "Loss of memory $B$ cells impairs maintenance of long-term serologic memory during HIV-1 infection," Blood, vol. 108, no. 5, pp. 15801587,2006

[76] H. Nagase, K. Agematsu, K. Kitano et al., "Mechanism of hypergammaglobulinemia by HIV infection: circulating memory B-cell reduction with plasmacytosis," Clinical Immunology, vol. 100, no. 2, pp. 250-259, 2001.

[77] A. De Milito, A. Nilsson, K. Titanji et al., "Mechanisms of hypergammaglobulinemia and impaired antigen-specific humoral immunity in HIV-1 infection," Blood, vol. 103, no. 6, pp. 2180-2186, 2004.

[78] L. J. Bernstein, H. D. Ochs, R. J. Wedgwood, and A. Rubinstein, "Defective humoral immunity in pediatric acquired immune deficiency syndrome," Journal of Pediatrics, vol. 107, no. 3, pp. 352-357, 1985.

[79] M. Imbeault, M. Ouellet, K. Giguère et al., "Acquisition of host-derived CD40L by HIV-1 in vivo and its functional consequences in the B-cell compartment," Journal of Virology, vol. 85, no. 5, pp. 2189-2200, 2011.

[80] S. Swingler, J. Zhou, C. Swingler et al., "Evidence for a Pathogenic Determinant in HIV-1 Nef Involved in B Cell Dysfunction in HIV/AIDS," Cell Host and Microbe, vol. 4, no. 1, pp. 63-76, 2008.

[81] S. Moir and A. S. Fauci, "Nef, macrophages and B cells: a highway for evasion," Immunology and Cell Biology, vol. 88, no. 1, pp. 1-2, 2010.

[82] B. He, X. Qiao, P. J. Klasse et al., "HIV-1 envelope triggers polyclonal Ig class switch recombination through a CD40independent mechanism involving BAFF and C-type lectin receptors," Journal of Immunology, vol. 176, no. 7, pp. 39313941, 2006.

[83] P. Rieckmann, G. Poli, C. H. Fox, J. H. Kehrl, and A. S. Fauci, "Recombinant gp120 specifically enhances tumor necrosis factor- $\alpha$ production and Ig secretion in B lymphocytes from HIV-infected individuals but not from seronegative donors," Journal of Immunology, vol. 147, no. 9, pp. 2922-2927, 1991.

[84] J. Ho, S. Moir, A. Malaspina et al., "Two overrepresented B cell populations in HIV-infected individuals undergo apoptosis by different mechanisms," Proceedings of the National Academy of Sciences of the United States of America, vol. 103, no. 51, pp. 19436-19441, 2006.

[85] A. Malaspina, S. Moir, D. G. Chaitt et al., "Idiopathic CD4+ $\mathrm{T}$ lymphocytopenia is associated with increases in immature/transitional B cells and serum levels of IL-7," Blood, vol. 109, no. 5, pp. 2086-2088, 2007.

[86] G. R. A. Ehrhardt, J. T. Hsu, L. Gartland et al., "Expression of the immunoregulatory molecule FcRH4 defines a distinctive tissue-based population of memory B cells," Journal of Experimental Medicine, vol. 202, no. 6, pp. 783-791, 2005.

[87] S. Moir, J. Ho, A. Malaspina et al., "Evidence for HIVassociated B cell exhaustion in a dysfunctional memory B cell compartment in HIV-infected viremic individuals," Journal 
of Experimental Medicine, vol. 205, no. 8, pp. 1797-1805, 2008.

[88] S. M. Schnittman, H. C. Lane, and S. E. Higgins, "Direct polyclonal activation of human B lymphocytes by the acquired immune deficiency syndrome virus," Science, vol. 233, no. 4768, pp. 1084-1086, 1986.

[89] S. Moir and A. S. Fauci, "Pathogenic mechanisms of Blymphocyte dysfunction in HIV disease," Journal of Allergy and Clinical Immunology, vol. 122, no. 1, pp. 12-19, 2008.

[90] S. Ghosh, O. Feyen, A. F. Jebran et al., "Memory B cell function in HIV-infected children-decreased memory B cells despite ART," Pediatric Research, vol. 66, no. 2, pp. 185-190, 2009.

[91] V. Bekker, H. Scherpbier, D. Pajkrt, S. Jurriaans, H. Zaaijer, and T. W. Kuijpers, "Persistent humoral immune defect in highly active antiretroviral therapy-treated children with HIV-1 infection: loss of specific antibodies against attenuated vaccine strains and natural viral infection," Pediatrics, vol. 118, no. 2, pp. e315-e322, 2006.

[92] C. Farquhar, D. Wamalwa, S. Selig et al., "Immune responses to measles and tetanus vaccines among Kenyan human immunodeficiency virus type 1 (HIV-1)-infected children pre- and post-highly active antiretroviral therapy and revaccination," Pediatric Infectious Disease Journal, vol. 28, no. 4, pp. 295-299, 2009.

[93] S. Pensieroso, A. Cagigi, P. Palma et al., "Timing of HAART defines the integrity of memory B cells and the longevity of humoral responses in HIV-1 vertically-infected children," Proceedings of the National Academy of Sciences of the United States of America, vol. 106, no. 19, pp. 7939-7944, 2009.

[94] M. C. Jacobsen, R. Thiébaut, C. Fisher et al., "Pediatric human immunodeficiency virus infection and circulating IgD + memory B cells," Journal of Infectious Diseases, vol. 198, no. 4, pp. 481-485, 2008.

[95] K. Titanji, F. Chiodi, R. Bellocco et al., "Primary HIV-1 infection sets the stage for important B lymphocyte dysfunctions," AIDS, vol. 19, no. 17, pp. 1947-1955, 2005.

[96] R. Spolski and W. J. Leonard, "The Yin and Yang of interleukin-21 in allergy, autoimmunity and cancer," Current Opinion in Immunology, vol. 20, no. 3, pp. 295-301, 2008.

[97] A. L. Rankin, H. MacLeod, S. Keegan et al., "IL-21 receptor is critical for the development of memory B cell responses," Journal of Immunology, vol. 186, no. 2, pp. 667-674, 2011.

[98] S. Pallikkuth, S. P. Kanthikeel, S. Y. Silva, M. Fischl, R. Pahwa, and S. Pahwa, "Upregulation of IL-21 receptor on B cells and IL-21 secretion distinguishes novel $2009 \mathrm{H} 1 \mathrm{~N} 1$ vaccine responders from nonresponders among HIV-infected persons on combination antiretroviral therapy," Journal of Immunology, vol. 186, no. 11, pp. 6173-6181, 2011.

[99] V. L. Bryant, C. S. Ma, D. T. Avery et al., "Cytokine-mediated regulation of human B cell differentiation into Ig-secreting cells: predominant role of IL-21 produced by CXCR5+ T follicular helper cells," Journal of Immunology, vol. 179, no. 12 , pp. 8180-8190, 2007.

[100] J. Publicover, A. Goodsell, S. Nishimura et al., "IL-21 is pivotal in determining age-dependent effectiveness of immune responses in a mouse model of human hepatitis B," Journal of Clinical Investigation, vol. 121, no. 3, pp. 1154-1162, 2011.

[101] M. B. Litinskiy, B. Nardelli, D. M. Hilbert et al., "DCs induce CD40-independent immunoglobulin class switching through BLyS and APRIL," Nature Immunology, vol. 3, no. 9, pp. 822-829, 2002.
[102] P. A. Moore, O. Belvedere, A. Orr et al., "BLyS: member of the tumor necrosis factor family and B lymphocyte stimulator," Science, vol. 285, no. 5425, pp. 260-263, 1999.

[103] P. Schneider, "The role of APRIL and BAFF in lymphocyte activation," Current Opinion in Immunology, vol. 17, pp. 282289, 2005.

[104] S. Pallikkuth, S. P. Kanthikeel, S. Y. Silva, M. Fischl, R. Pahwa, and S. Pahwa, "Innate immune defects correlate with failure of antibody responses to H1N1/09 vaccine in HIV-infected patients," Journal of Allergy and Clinical Immunology, vol. 128, no. 6, pp. 1279-1285, 2011.

[105] A. Cagigi, A. Nilsson, S. Pensieroso, and F. Chiodi, "Dysfunctional B-cell responses during HIV-1 infection: implication for influenza vaccination and highly active antiretroviral therapy," The Lancet Infectious Diseases, vol. 10, no. 7, pp. 499-503, 2010.

[106] C. G. Sutcliffe and W. J. Moss, "Do children infected with HIV receiving HAART need to be revaccinated?” The Lancet Infectious Diseases, vol. 10, no. 9, pp. 630-642, 2010.

[107] A. Nilsson and F. Chiodi, "Measles outbreak in Africa-is there a link to the HIV-1 epidemic?" PLoS Pathogens, vol. 7, no. 2, Article ID e1001241, 2011.

[108] I. J. Amanna, N. E. Carlson, and M. K. Slifka, "Duration of humoral immunity to common viral and vaccine antigens," New England Journal of Medicine, vol. 357, no. 19, pp. 19031915, 2007.

[109] S. Moir, C. M. Buckner, J. Ho et al., "B cells in early and chronic HIV infection: evidence for preservation of immune function associated with early initiation of antiretroviral therapy," Blood, vol. 116, no. 25, pp. 5571-5579, 2010.

[110] P. Palma, M. L. Romiti, S. Bernardi et al., "Safety and immunogenicity of a monovalent MF59-adjuvanted A/H1N1 vaccine in HIV-infected children and young adults," Biologicals. In press.

[111] A. Barkhordarian, N. Iyer, P. Shapshak et al., "Influenza 2009 pandemic: cellular immunemediated surveillance modulated by TH17 \& Tregs," Bioinformation, vol. 6, no. 1, pp. 39-40, 2011.

[112] Y. He, J. Li, Y. Zheng et al., "A randomized case-control study of dynamic changes in peripheral blood Th17/Treg cell balance and interleukin-17 levels in highly active antiretroviraltreated HIV Type 1/AIDS patients," AIDS Research and Human Retroviruses. In press.

[113] L. C. Ndhlovu, J. M. Chapman, A. R. Jha et al., "Suppression of HIV-1 plasma viral load below detection preserves IL-17 producing T cells in HIV-1 infection," AIDS, vol. 22, no. 8, pp. 990-992, 2008.

[114] K. Rainwater-Lovett and W. J. Moss, "Immunologic basis for revaccination of HIV-infected children receiving HAART," Future Virology, vol. 6, no. 1, pp. 59-71, 2011.

[115] S. K. Obaro, D. Pugatch, and K. Luzuriaga, "Immunogenicity and efficacy of childhood vaccines in HIV-1-infected children," Lancet Infectious Diseases, vol. 4, no. 8, pp. 510-518, 2004.

[116] M. Zanchetta, A. Anselmi, D. Vendrame et al., "Early therapy in HIV-1-infected children: effect on HIV-1 dynamics and HIV-1-specific immune response," Antiviral Therapy, vol. 13, no. 1, pp. 47-55, 2008.

[117] K. Luzuriaga, M. McManus, M. Catalina et al., "Early therapy of vertical human immunodeficiency virus type 1 (HIV1) infection: control of viral replication and absence of persistent HIV-1- specific immune responses," Journal of Virology, vol. 74, no. 15, pp. 6984-6991, 2000. 
[118] F. Buseyne, D. Scott-Algara, N. Bellal, M. Burgard, S. Blanche, and Y. Rivière, "The frequency of HIV-specific interferon- $\gamma$ producing CD8 $\mathrm{T}$ cells is associated with both age and level of antigenic stimulation in HIV-1-infected children," Journal of Infectious Diseases, vol. 192, no. 10, pp. 1781-1786, 2005.

[119] F. Buseyne, D. Scott-Algara, F. Porrot et al., "Frequencies of ex vivo-activated human immunodeficiency virus type 1-specific gamma-interferon-producing CD8 $+\mathrm{T}$ cells in infected children correlate positively with plasma viral load," Journal of Virology, vol. 76, no. 24, pp. 12414-12422, 2002.

[120] P. Palma, M. L. Romiti, C. Cancrini et al., "Delayed early antiretroviral treatment is associated with an HIV-specific longterm cellular response in HIV-1 vertically infected infants," Vaccine, vol. 26, no. 40, pp. 5196-5201, 2008.

[121] A. Viganò, D. Trabattoni, L. Schneider et al., "Failure to eradicate HIV despite fully successful HAART initiated in the first days of life," Journal of Pediatrics, vol. 148, no. 3, pp. 389-391, 2006.

[122] M. Hainaut, C. A. Peltier, M. Gérard, D. Marissens, G. Zissis, and J. Levy, "Effectiveness of antiretroviral therapy initiated before the age of 2 months in infants vertically infected with human immunodeficiency virus type 1," European Journal of Pediatrics, vol. 159, no. 10, pp. 778-782, 2000.

[123] M. Hainaut, C. A. Peltier, T. Goetghebuer et al., "Seroreversion in children infected with HIV type 1 who are treated in the first months of life is not a rare event," Clinical Infectious Diseases, vol. 41, no. 12, pp. 1820-1821, 2005.

[124] S. Kassutto, M. N. Johnston, and E. S. Rosenberg, "Incomplete HIV type 1 antibody evolution and seroreversion in acutely infected individuals treated with early antiretroviral therapy," Clinical Infectious Diseases, vol. 40, no. 6, pp. 868873, 2005.

[125] Z. A. Scott, E. G. Chadwick, L. L. Gibson et al., "Infrequent detection of HIV-1-specific, but not cytomegalovirusspecific, CD8+ T cell responses in young HIV-1-infected infants," Journal of Immunology, vol. 167, no. 12, pp. 71347140, 2001.

[126] E. S. Rosenberg, J. M. Billingsley, A. M. Caliendo et al., "Vigorous HIV-1-specific CD4+ T cell responses associated with control of viremia," Science, vol. 278, no. 5342, pp. 14471450, 1997.

[127] J. K. Sandberg, N. M. Fast, K. A. Jordan et al., "HIV-specific $\mathrm{CD} 8+\mathrm{T}$ cell function in children with vertically acquired HIV-1 infection is critically influenced by age and the state of the CD4+ T cell compartment," Journal of Immunology, vol. 170, no. 8, pp. 4403-4410, 2003.

[128] W. Borkowsky, M. X. Zhan, S. H. Chen et al., "Correlation between HIV-specific CD8 cell production of interferon$\gamma$ and plasma levels of HIV RNA in perinatally infected pediatric populations," Journal of Infectious Diseases, vol. 190, no. 4, pp. 722-726, 2004.

[129] A. M. Geretti and T. Doyle, "Immunization for HIV-positive individuals," Current Opinion in Infectious Diseases, vol. 23, no. 1, pp. 32-38, 2010. 


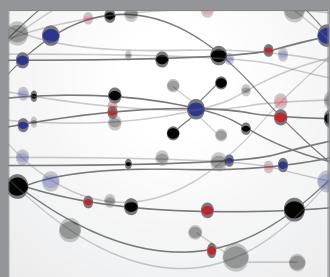

The Scientific World Journal
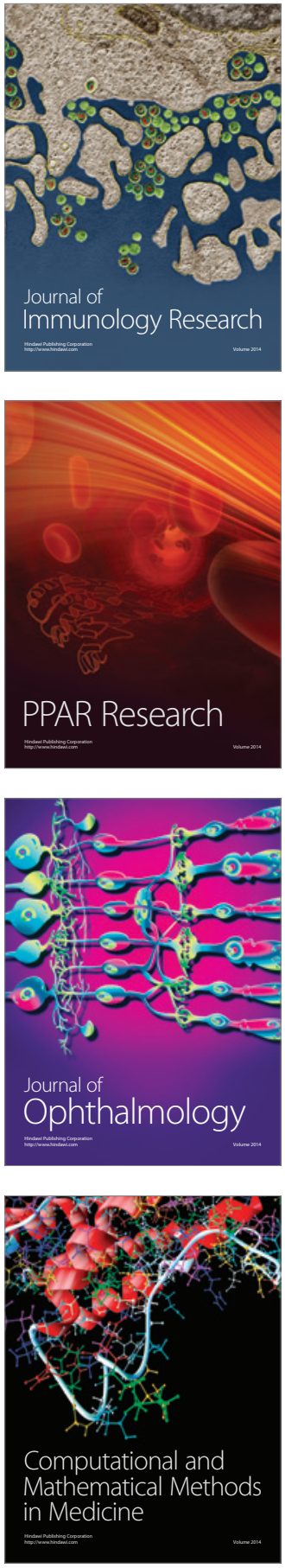

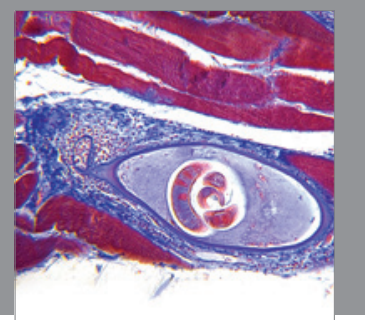

Gastroenterology

Research and Practice
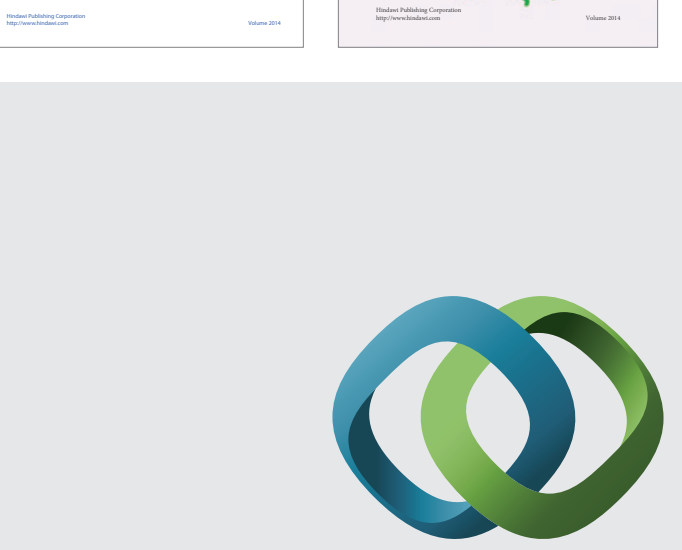

\section{Hindawi}

Submit your manuscripts at

http://www.hindawi.com
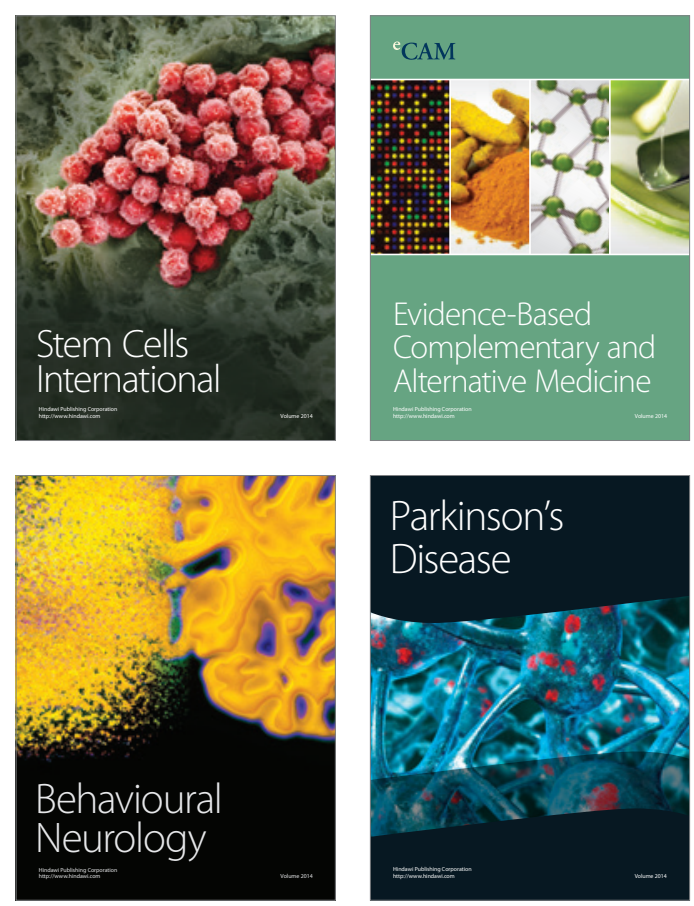

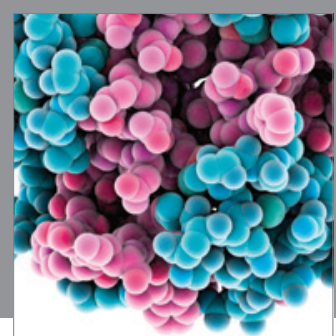

Journal of
Diabetes Research

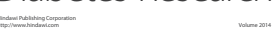

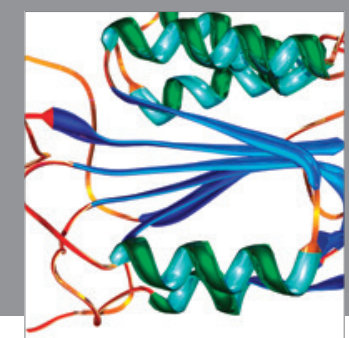

Disease Markers
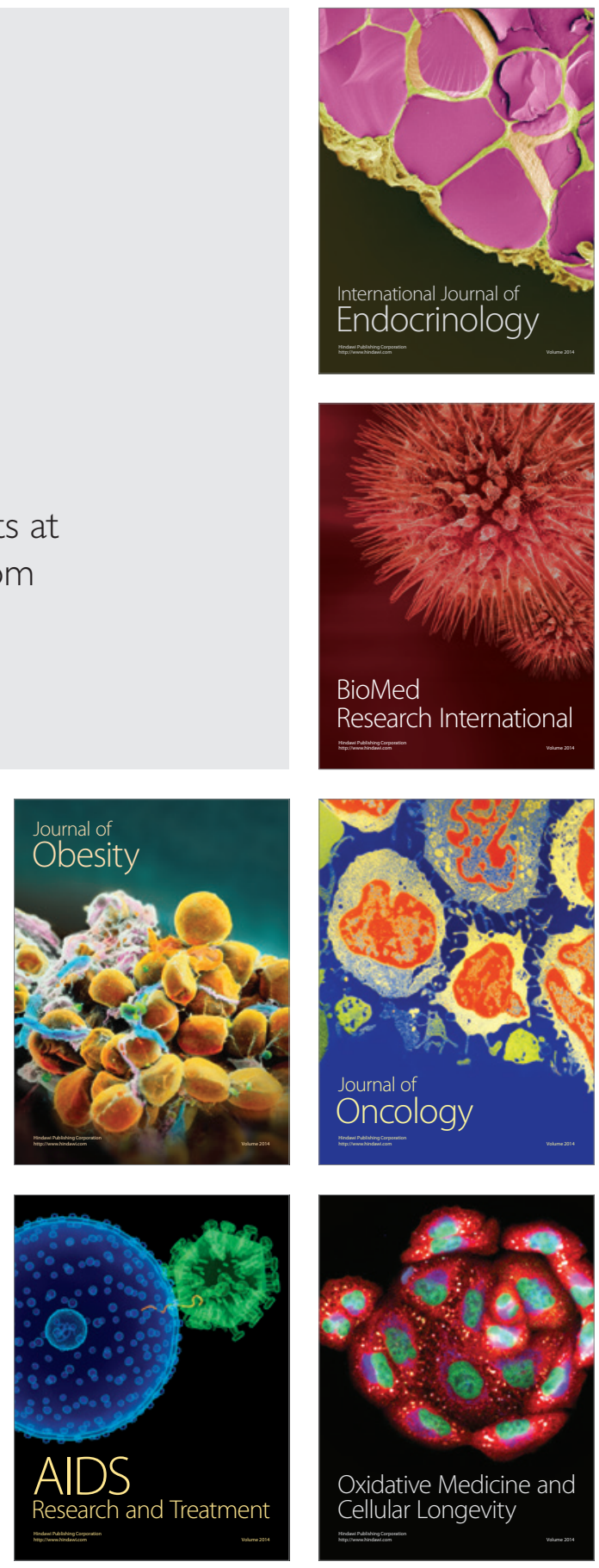